\title{
Devadesát let od založení Ústavu archeologie a muzeologie
}

\section{Ninety years since the founding of the Department of Archaeology and Museology}

\author{
Jiří Macháček
}

\section{Dámy a pánové,}

Masarykova univerzita oslavila v roce 2018 sté výročí svého vzniku. Letos oslavujeme výročí méně kulaté i méně velkolepé, přesto však pro mnohé z nás důležité. Před 90 lety byl v Brně na filozofické fakultě zřízen usnesením tamějšího děkanství ze dne 16. června 1930 Ústav pro prehistorii a protohistorii. Jeho vedení se po menších peripetiích ujal o rok později Emanuel Šimek, který předtím působil ve Vídni v aparátu rakousko-uherské státní památkové péče a později vyučoval v Praze. Rozjezd nové katedry, jejíž založení spadá do období velké hospodářské krize, provázely značné problémy. Zprvu neměla ani své vlastní prostory a přednášky probíhaly ve společných fakultních učebnách. Až v roce 1934 získal Šimkův ústav tři skromně vybavené místnosti v budově bývalého sirotčince, dnes historického sídla filozofické fakulty, aby se o něco později přesunul do prostor $\mathrm{v}$ jiné části fakultního komplexu, kde katedra sídlila až do nedávna. Šimkovi se podařilo zřídit sice malou, ale funkční vysokoškolskou katedru, kterou řídil pevnou rukou bývalého námořního důstojníka c. a k. maríny.
Emanuel Šimek by se asi velice podivil, co z jeho malé katedry, kterou na počátku tvořil jen on, zřízenec Ústavu - bývalý ruský legionář Josef Volšík, a tři studenti prehistorie, po 90 letech vyrostlo. Nelze však říci, že by se ústav vždy vyvíjel kontinuálně a bez výkyvo̊. Někdy mohutněl, zvláště v 50. a 60. letech 20. stol. pod taktovkou prof. Františka Kalouska - Šimkova žáka a jednoho z protagonistů boomu velkomoravské archeologie, jindy strádal - zvláště na konci 80 . let, kdy byla archeologie pokládána za útlumový obor a katedra ztratila na čas dokonce svoji samostatnost. Těžkým obdobím byla i poslední dekáda 20. století, kdy probíhala nezbytná, ale bolestná transformace české společnosti. Od začátku nového milénia však prožívá Ústav archeologie a muzeologie na Masarykově univerzitě štastná léta. Ve všech ohledech se rozrostl a integroval různé obory - kromě tradiční archeologie střední Evropy i archeologii klasickou, zaměřenou na antický svět, a muzeologii, která připravuje profesionály pro naše pamětové instituce. Dnes zde studuje 185 studentů bakalářského a magisterského cyklu a 48 doktorandů. I to byl jeden z důvodů, proč se tehdejší vedoucí ústavu prof. Zdeněk Měřínský začal rozhlížet po nových prostorách, protože místnosti, které sta- 
čily Emanuelu Šimkovi ve 30. letech již absolutně nesplňovaly nároky sebevědomého a moderního univerzitního pracoviště s evropskými ambicemi. Zdeněk Měřínský si vyhlédl budovu bývalého chemického pavilonu německé techniky na Joštově 13 , odkud se měl do nového kampusu vystěhovat fyziologický ústav profesora Fišera. Od prvotního nápadu to trvalo devatenáct let než se nakonec po trojím náročném stěhování a dvouleté opravě celé budovy $\mathrm{M}$ financované z prostředků Ministerstva školství, mládeže a tělovýchovy ČR a Masarykovy univerzity mohli archeologové a muzeologové do rekonstruované budovy nastěhovat. Historizující styl architektury s mnoha odkazy na antické vzory odpovídá povaze těchto oborů mnohem lépe, než tomu bylo u dřivějších nájemců - exaktních medicinských oborů, které se dnes usadily ve futuristických budovách nového univerzitního kampusu. Po rekonstrukci se však díky citlivému architektonickému projektu i pavilon z roku 1898 stala moderní infrastrukturou, která plně odpovídá potřebám pracoviště zařazeného podle mezinárodního žebříčku QS World University Rankings jako jediné z České republiky mezi 200 nejlepších kateder archeologie světa. Kromě obligátních učeben vybavených multimediálními prezentačními technologiemi, zde najdeme archeologické laboratoře pro konzervaci archeologických nálezů, traseologickou laboratoř vybavenou výkonnými mikroskopy pro výzkumníky i studenty, geofyzikální pracoviště $\mathrm{s}$ řadou př́strojů pro archeologickou prospekci, unikátní národní litotheku kamenných surovin životní dílo prof. A. Přichystala, 3D laboratoř pro komplexní digitalizaci artefaktů či sídlo populární Internetové encyklopedie Brna, díky níž Ústav archeologie a muzeologie úspěšně plní i tzv. třetí roli univerzity ve veřejném prostoru. Chloubou je rozsáhlá knihovna, která se rozrostla z původních 482 knih shromážděných Emanuelem Šim- kem na úctyhodný fond tvořený více než 50000 svazky. Faktickým i symbolickým středem budovy je zastřešené atrium, které slouží jako komunitní prostor a zároveň jako muzeologická dílna pro menší výstavy, realizované studenty muzeologie a jejich pedagogy.

Slavnostním otevřením nové budovy v roce 90. výročí svého vzniku zahajuje Ústav archeologie a muzeologie novou éru. Věříme, že díky investicím do nové infrastruktury to bude doba neméně tak úspěšná, jako léta minulá a že archeologie na Masarykově univerzitě bude i nadále vzkvétat. Věříme, že nezklameme důvěru, kterou v nás vložilo vedení Masarykovy univerzity, které ještě pod vedením rektora Mikuláše Beka svolilo k ponechání budovy M filozofické fakultě a jejímu Ústavu archeologie a muzeologie. Upřímně děkujeme vedení filozofické fakulty pod vedením děkana Milana Pola, že umožnilo rekonstrukci těchto prostor, a především tajemníkovi fakulty panu Ivo Jurtíkovi, který s obrovským osobním nasazením celý náročný proces organizoval. Naše díky patří i architektům z Atelieru X a z projekční firmy INTAR a. s., stejně jako zhotovitelské firmě IMOS a jejím stavbyvedoucím, kteří věnovali rekonstrukci památkového objektu nadstandardní péči. Za úspěšnou památkovou obnovu míří naše poděkování i k brněnskému pracovišti Národního památkového ústavu a Odboru památkové péče Magistrátu města Brna. Zcela zásadní roli v přípravné fázi i během realizace stavby sehrály Irena Loskotová a Jitka Šibíčková, které týden co týden konzultovaly průběh prací $\mathrm{z}$ hlediska uživatele a společně $\mathrm{s}$ architekty celý projekt připravovaly. Naše vzpomínka patří Zdeňku Měřínskému, dlouholetém ordináriovi archeologie na filozofické fakultě, který se realizace svého snu o novém sídle Ústavu archeologie a muzeologie sice nedožil, ale který by byl jistě s tímto dílem spokojen. 